\title{
DEVELOPMENT OF CONSTRUCTIVE-TECHNOLOGICAL SCHEME OF PARKING FOR AGRICULTURAL MACHINERY
}

\author{
Nikolai Skuryatin, Alexander Novitsky, Anatoly Zhiltsov, Evgeniy Soloviev \\ Belgorod State Agricultural University named after V. Gorin, Russia \\ sku.nauka@gmail.com, alex.bel77@yandex.ru,tola260144@mail.ru, solovyewww@mail.ru
}

\begin{abstract}
The closed method of storing agricultural machinery is more effective than the open one, but it is also the most expensive. In this way, garages, hangars, sheds etc. are used and at the same time it takes into consideration only the area, not the volume. In this article we solved the problem of using the volume of the room where the equipment is stored. It is proposed to place equipment on three levels. The first level is the floor, where it is advisable to place power equipment. The second level includes agricultural machinery - cultivators, seeders, plant protection machines, etc. It is formed from L-shaped platforms, controlled by four-link mechanisms attached to the facade wall. Four-link mechanisms carry out lifting of agricultural machines fixed on L-shaped platforms. Electric winches serve as the driving mechanism. Spontaneous lowering of the L-shaped platforms is excluded due to the stops that are installed under the platforms. At the third level we can hang smallsized equipment and containers with spare parts for machines by the brackets attached to the front wall. Suspension is carried out by means of a crane beam. By applying a modernized hook we can solve the problem of disconnecting and connecting the lifting hook with the ring on the load (small-sized equipment, containers). Modernized hook is equipped with a rotation mechanism around the vertical axis and a branch pipe in the form of a ring. There are nozzles on the ring. Compressed air is supplied to the branch pipe and, accordingly, to the nozzles. The hook is rotated in the right direction and deviated in the direction of the ring on the load by means of the console. The use of the modernized hook of the lifting device allows it to be connected and disconnected with the ring on the load at a distance inaccessible to the operator. Technical and economic efficiency is ensured by placing a larger number of machines in the room with closed storage.
\end{abstract}

Keywords: storing, placement levels, volume, four-link mechanisms, hook.

\section{Introduction}

Most of agricultural machines (plows, cultivators, seeders, combines) because of the narrow specialization and seasonality of work are used during the year for a short time, usually less than 10$15 \%$ of the year time. Tractors are more loaded (up to 1350 hours). However, they also have long non-working periods during the year.

Depending on the duration of the non-working periods of machines and units, there are two types of their storage: short-term and long-term.

There are three ways to store machines: indoor, outdoor and combined. Their use is due to the design features of the machines, climatic conditions of the industry, the presence of appropriate facilities or open areas.

The indoor method is the most effective in terms of safety of equipment, but it is more expensive, because only the area of the room is used, but not its volume. In the proposed project the task is to place agricultural machines on two or more levels in the room.

The analysis of technical and patent literature proved that the indoor method of storage of mobile equipment (vehicles) is well developed by using parking lots of various design and technological schemes [1-5], but agricultural machinery is represented mainly by hinged and trailed machines, which are put in storage with the use of tractors, placing them in rows on platforms or under canopies. The placement of agricultural machinery on the second level was not considered.

At the Department of Technical Service in the Belgorod State Agricultural University named after V. Gorin a design and technological scheme of a parking lot for agricultural machinery were developed [6], where the equipment is located on two levels. The second level is formed of L-shaped platforms controlled by four-link mechanisms hinged to the front wall and providing plane-parallel lifting machines to the second level.

\section{Materials and methods}

Consider the design and technological scheme of a parking lot, the sequence of operations in the formulation of equipment for storage, the positive aspects and ways to improve the scheme. 
The parking lot for agricultural machinery (Fig. 1) has a central wall 1 with mounted fasteners 2 on both sides, the lower and upper fasteners are pivotally attached to the lower and upper beams 3 and 4 , and their lengths are equal. To the free ends of the lower 3 and upper 4 beams, the upper parts of the L-shaped platforms 5 are rigidly connected with horizontal ends to the valves 6 , which are rigidly connected with the possibility of transferring them in a vertical position due to the lifting drives of the valves 7 installed in the upper parts of the L-shaped platforms 5 and equipped with cables 8 rigidly connected to the ends of the valves 6 . The lifting drives of the 9 L-shaped platforms 5 are rigidly attached to the fasteners 2 installed on both sides in the upper part of the central wall 1, equipped with cables 10 , the lower ends of which are rigidly attached to the middle of the vertical parts of the Lshaped platforms 5 . The distance between the lower and upper fasteners 2 is greater than the height of the tractor, and the length of the beams 3 and 4 is greater than its wheel track. The free ends of the beams 3 are pivotally attached to the supports 11, and their length is less than the length of the beams 3 , and their lower ends are in contact with the sockets 12 made in the floor of the parking lot, and in the middle of the beams 3 is rigidly connected to the stop clamps 13 .

At the moment of setting agricultural machinery for long-term storage the L-shaped platform 5 under the influence of the drives 9 and 10 cables is lowered down, the valves 6 under the influence of the drives 7 and 8 cables from the vertical position are transferred to the horizontal position. Mobile machines (tractors) are installed on the first level next to the central wall 1 on both sides, on the valves 6 trailed and hinged machines are installed (for example, seeders, cultivators).

By drive 9 cables 10, the lower ends of which are rigidly attached to the middle of the vertical part of the L-shaped platforms 5, the seeders are lifted into the second level. Lowering of seeders occurs in the reverse order.

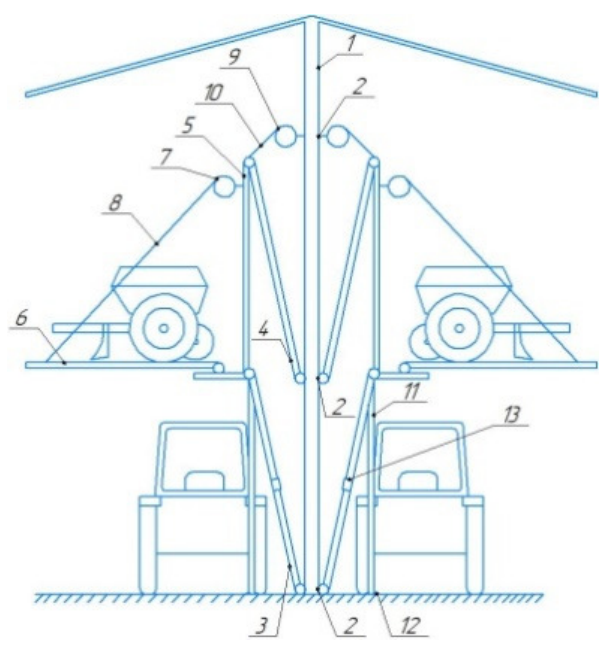

Fig. 1. Parking lot for agricultural machinery: 1 - central wall; 2 -fasteners; 3,4 - lower and upper beam; 5 - L-shaped platforms; 6 - valves; 7 - valve lift drive; 8 - cables ofthe drive lifting;

9 - lift drives of L-shaped platforms; 10 - cables of the drive of lifting of L-shaped platforms; 11 - stops; 12 - sockets; 13 - stop clamps

Mobile vehicles (tractors) are parked on the first level along the central wall of the parking lot for agricultural machinery, after the L-shaped platforms are lowered into the lower position (Fig. 2), where trailed machines (seeders and cultivators) are placed. Then, by means of the lifting drives of the L-shaped platforms lifting of trailed machines (seeders) is carried out on the second level. For the safety of the operators, the stops are removed from the clamps rigidly attached to the beams and their lower ends are placed in the sockets made in the parking floor (Fig. 1). If there is no need to place agricultural machinery in the parking lot, then the parking lot for agricultural machinery is used as a storage room, for this purpose the L-shaped platforms are raised up to the second level, also the valves are raised to the vertical position (Fig. 3).

By means of the preliminary calculations the parking area equal to the area for storage of 16 units of agricultural machinery allows to store twice as many agricultural machines and provides savings of more than 500 thousand rubles in comparison with the construction of a single-level parking lot, while not taking into account the savings from the preservation of machines and extend service life. 
The findings point to the feasibility of developing a constructive and technological scheme of three and four-level parking lots.

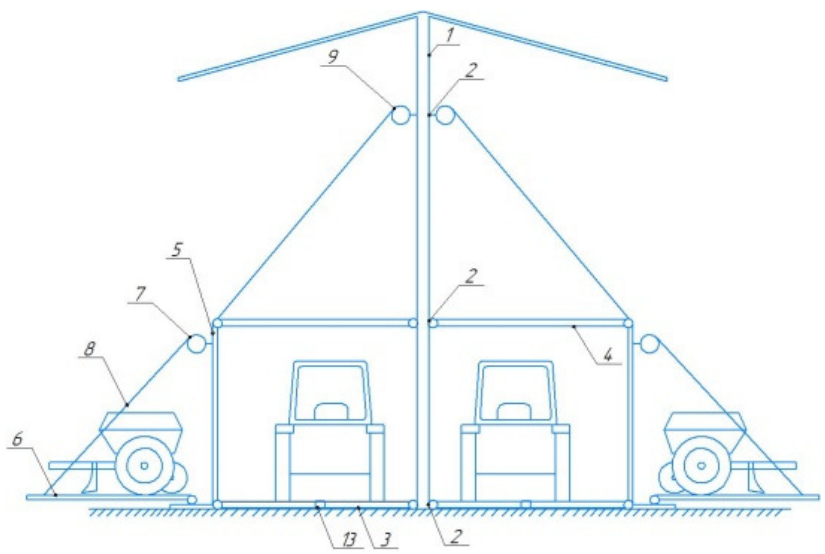

Fig. 2. Preparation for rising up planters on the second level

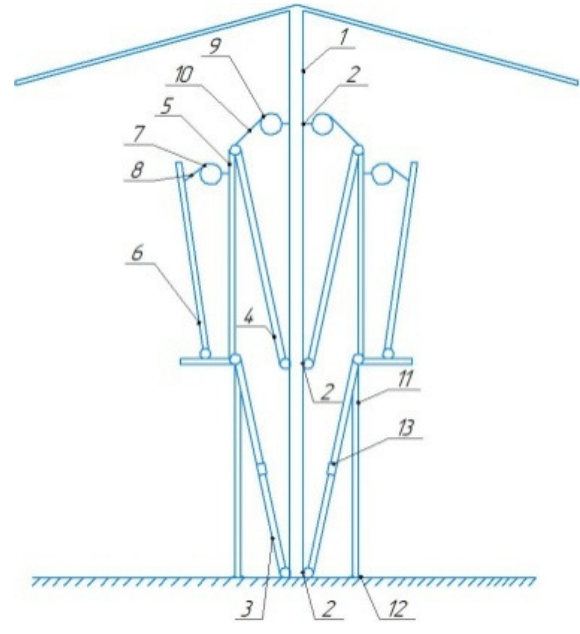

Fig. 3. Non-performing parking lot

The third level of placement of small-sized equipment and containers with spare parts and equipment is made by hanging them on brackets mounted in the facade walls using S-shaped hooks with stops in the middle part, and the lower part of the S-shaped hook captures the cargo (container, small - sized agricultural machine), and the upper-is used for connection with the hook of the lifting device. The free ends of the brackets are made in the form of a "dovetail", where the S-shaped hook is mounted and the load is lowered to the contact of the S-shaped hook stop with the free end of the bracket.

Herewith, a problem appeared of connection and detachment of a hook of the load-lifting device with a ring on the lifted load since the load is at visible, but inaccessible distance to the operator. There was a task to create a "controlled" hook suitable for rotation around the vertical axis and shift from the vertical position in the right direction.

There are no technical solutions for connecting the hook of the lifting device with the ring on the load without participation of the slinger [8-10], so the hook of the lifting device is proposed with the ability to rotate around the vertical axis and shift to the desired direction.

The lifting device (Fig. 4) consists of a cable 1, which is rigidly fixed to the bracket 2 in the hole. In the lower part of the bracket 2, the upper end of the hook 10 is placed, on which the thrust bearing 9 is mounted, and the nuts 8 are mounted above the thrust bearing 9 , and the driven gear 7 is rigidly mounted above the nuts 8 at the upper end of the hook 10. The driven gear 7 contacts the drive gear 6 , which is rigidly mounted on the output end of the gear shaft 5 , which is rigidly attached to the motor 4 . Above the electric motor 4 a gas cylinder 11 is installed, connected to supply the device of compressed air to the nozzles 12 , which are rigidly attached to the gas cylinder 11 . Moreover, to supply the device of compressed air to the nozzles 12, tubes are attached to nozzles 14, the lower ends of which are rigidly attached along the perimeter of the hoop 3 installed in the lower part of the bracket 2, the electric motor 4 and the supply device of compressed air to the nozzles 12 are connected to the control panel 15.

The lifting device works as follows - the control panel 15 turns on the electric motor 4, as a result of this, the driving 6 and the driven 7 gears interact by rotating, which turns the point of the hook 10 towards the ring on the lifted load at an unattainable distance. The hook point is directed perpendicular to the plane in which the ring is positioned, the hook 10 is rotated in the thrust bearing 9. In this position, by means of the control panel of the lifting device, the point of the hook 10 and the ring on the lifted load are approached. Then, the control panel of the supply device of compressed air to the nozzles and the electric motor 15 through the tubes with nozzles 14 located on the opposite side of the hook from the gas cylinder 11 feed gas (Fig. 5). As a result of the action of the reactive force acting on the hoop 3, fixed to the bracket 2, the toe of the hook is introduced into the ring and the load is lifted. When lowering the load, the withdrawal of the hook point 10 from the ring on the lifted load is carried 
out by supplying air through the tubes with nozzles 14 attached to the hoop 3 from the side of the hook point (Fig. 6).

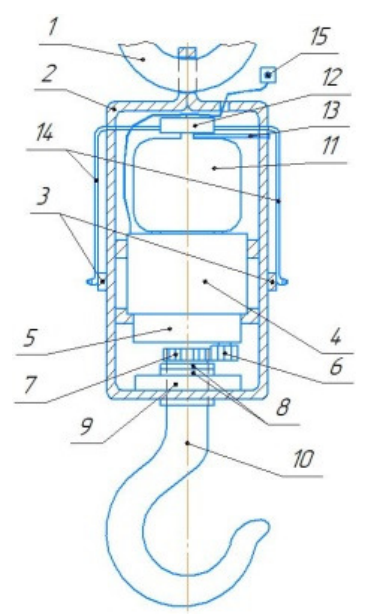

Fig. 4. Scheme of lifting and transport device with pneumatic drive: 1 - cable; 2 - bracket; 3 - hoop; 4 - electric motor; 5 - reducer; 6 - drive gear; 7 - driven gear; 8 - nuts; 9 - thrust bearing; 10 - hook; 11 - compressed air cylinder; 12 - supply device of compressed air to the nozzles; 13 - tube for supplying compressed air to the cylinder; 14 - tubes with nozzles; 15 - control panel for compressed air supply to the nozzles and the motor

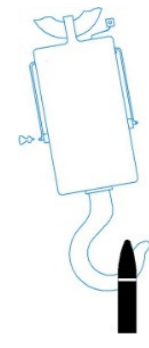

Fig. 5. Scheme of connection of hook with ring on cargo

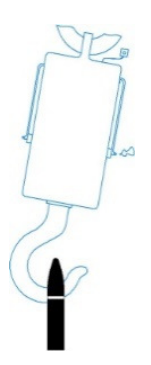

Fig. 6. Scheme of hook-ring separation on cargo

While performing loading and unloading operations, the hook of the lifting device, usually, makes oscillating movements. They are usually dampened by the hands of the operator and then the operator carries the hook load. In this case, this function is performed by a controlled hook with a pneumatic drive.

\section{Results and discussion}

Here is an example of calculating the main parameters of the process of connecting the controlled hook with the load, which in our case are: the damping time of the hook vibrations and the force that provides its excursion by a given angle. The oscillation scheme of the hook with a pneumatic drive is shown in Fig.7.

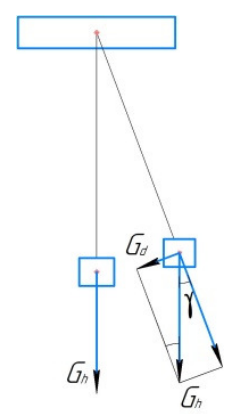

Fig. 7. Scheme of oscillation of hook with pneumatic drive

Determine the value of the force deflecting the hook $[11 ; 12]$ : 


$$
\sin \gamma=\frac{G_{d}}{G_{h}},
$$

where $G_{d}$ force, deflecting (braking) the hook, N;

$G_{h}$ - hook weight, N;

$\gamma$ - angle of excursion from the vertical cable.

Where:

$$
G_{d}=G_{h} \cdot \sin \gamma=\frac{\pi \cdot d^{2} \cdot \rho}{4},
$$

where $d$-nozzle diameter, $\mathrm{m}$;

$\rho$ - specific pressure in the pneumatic system of the hook, $\mathrm{N} \cdot \mathrm{m}^{-2}$.

It is important to know the value of the specific pressure in the pneumatic system of the hook, sufficient to deflect the hook of a certain mass. For a given nozzle diameter, it can be determined from the equation(2):

$$
\rho=\frac{4 G_{h} \cdot \sin \gamma}{\pi \cdot d^{2}} .
$$

Here is an example of calculation of the specific pressure value in the pneumatic system, assumed: $d=0.01 \mathrm{~m}$ and the weight of the hook $120 \mathrm{~N}$, deviation angle of the cable from vertical axis $10^{\circ}$, then the pressure in the pneumatic system of the hook is equal to:

$$
\rho=\frac{4 \cdot 120 \cdot \sin 10^{\circ}}{3.14 \cdot 0.01^{2}}=265445 \mathrm{~N} \cdot \mathrm{m}^{-2}=2.7 \mathrm{MPa} .
$$

With the use of the equations of dynamics of rotational motion at small angles of deviation of the cable from the vertical the damping time of the hook vibrations is determined in the first approximation.

With the use of the equations of rotational motion dynamics at small angles deviation of the cable from the vertical axis in the first approximation the damping time of the hook vibrations is calculated.

It is assumed that the hook on the rope is a physical pendulum.

Due to the air friction in the suspension, the mechanical energy of the pendulum is scatter as heat, so the oscillations are damped. Since the pendulum makes rotational movements relative to the fixed axis, they are described by the basic equation of the rotational motion dynamics [11;12]:

$$
M=I \cdot \frac{d^{2} \varphi}{d t^{2}}=I \cdot \varepsilon,
$$

where $\varphi$-deflection angle of the pendulum;

$\varepsilon=d^{2} \varphi / d t^{2}-$ angular acceleration, $\mathrm{rad} \cdot \mathrm{s}^{-2}$

$I$ - moment of inertia of the pendulum relative to the axis of suspension, $\mathrm{kg} \cdot \mathrm{m}^{2}$;

$M$ - resulting moment of all forces acting on the body, $\mathrm{N} \cdot \mathrm{m}$.

It is made up of the rotational moment created by gravity, $M_{\text {rot }}=-m \cdot g \cdot l \cdot \sin \varphi$, the braking torque generated by the friction forces:

$$
M_{b r}=-r \cdot \omega,
$$

where $r$-coefficient of friction;

$$
\omega=d \varphi / d t-\text { angular velocity, } \mathrm{rad} \cdot \mathrm{s}^{-1} .
$$

The "-" sign in the formula for the rotational moment reflects the fact that the returning force is always directed to the equilibrium position, in the direction of decreasing the angle. The "-" sign in the formula for the braking torque is due to the fact that the direction of the friction force is always opposite to the direction of motion. 
At small angles of deviation, it is possible to consider $\sin \varphi \cong \varphi$, then $M_{r o t}=-m \cdot g \cdot l \cdot \varphi$ and equation (4) can be represented as:

$$
I \cdot \frac{d^{2} \varphi}{d t^{2}}+r \cdot \frac{d \varphi}{d t}+m \cdot g \cdot l \cdot \varphi=0
$$

Dividing all terms by $I$ and by entering the notation:

$$
\frac{r}{I}=2 \cdot \beta, \frac{m \cdot g \cdot l}{I}=\omega_{0}^{2},
$$

where $\beta$-attenuation coefficient;

$\omega_{0}$ - eigenfrequency of undamped oscillations of the pendulum, consider the differential equation of free damped oscillations:

$$
\frac{d^{2} \varphi}{d t^{2}}+2 \cdot \beta \cdot \frac{d \varphi}{d t}+\omega_{0}^{2} \cdot \varphi=0
$$

The solution to this equation is the function:

$$
\varphi=A_{0} \cdot e^{-\beta \cdot t} \cdot \sin \left(\omega \cdot t+\alpha_{0}\right) .
$$

Multiplier $A=A_{0} \cdot e^{-\beta \cdot t}$ represents the amplitude of the damped oscillations at a time $t ; A_{0}-$ amplitude at the initial time. The expression under the sign of the sin-the phase of the oscillation at any time $t, \alpha_{0}$ - initial phase $(t=0), \omega$ - cyclic frequency of damped oscillations.

$$
I=m l^{2},
$$

where $l$-length of the cable, $\mathrm{m}, l=10 \mathrm{~m}$;

$m$ - weight of the lifting device, $\mathrm{kg}$.

$$
\beta=\frac{a}{2 l},
$$

where $a$ - viscosity of air, $a=17.20$ (at temperature $0^{\circ} \mathrm{C}$ ).

$$
\frac{A}{A_{0}}=\frac{1}{100}=\frac{1}{e^{\beta \cdot t}} \Rightarrow e^{\beta \cdot t}=100, \beta \cdot t=\log _{e} 100, \log _{e} 100=4.61 \Rightarrow t=\frac{4.61}{17.20} \cdot 200 \mathrm{~m}
$$

Time of damped oscillations:

$$
t=53.60465 \mathrm{~m} \text {. }
$$

The calculations of the time of damped oscillations for hooks of different masses are entered in Table 1 .

Technical characteristics of hooks

\begin{tabular}{|c|c|c|}
\hline $\begin{array}{c}\text { Loadcapacity, } \\
\text { ton }\end{array}$ & $\begin{array}{c}\text { Mass of the } \\
\text { product, } \mathbf{~ k g}\end{array}$ & $\begin{array}{c}\text { Time of damping of } \\
\text { vibrations of the hook, min }\end{array}$ \\
\hline 0.4 & 0.18 & 0.17 \\
\hline 0.5 & 0.22 & 0.2 \\
\hline 1.0 & 0.6 & 0.5 \\
\hline 1.6 & 1.5 & 1.33 \\
\hline 2.0 & 1.7 & 1.51 \\
\hline 2.5 & 2.6 & 2.32 \\
\hline 3.2 & 4.1 & 3.67 \\
\hline 4.0 & 4.5 & 4.02 \\
\hline 5.0 & 8.9 & 7.95 \\
\hline 8.0 & 13.5 & 12.07 \\
\hline
\end{tabular}

From Table 1 it is seen that depending on the lifted load (agricultural machines), and therefore the applied load-lifting device, the damping time of the oscillations of the hook can reach 12 min. 
The use of hooks in lifting devices with pneumatic drive will reduce to zero the damping time of their oscillations, which will significantly improve the performance of loading and unloading operations at a visible but inaccessible distance for the slinger.

\section{Conclusions}

1. Analysis of technical solutions for storage of vehicles shows that a wide range of parking lots of various structural and technological schemes are developed and used that can store vehicles on several levels, but parking lots for storage of trailed and hinged agricultural machines are not developed. In this regard, a constructive and technological scheme of three-level parking for agricultural machinery has been developed, and at the third level relatively light and small-sized machines and containers with spare parts and equipment are placed through the use of lifting devices and special brackets rigidly mounted in the facade walls.

The second level consists of L-shaped platforms on which the machines are installed, with each platform controlled by a four-link mechanism, also pivotally attached to the front wall. The first level houses mobile equipment (tractors and self-propelled agricultural machinery).

2. The arisen problem of connection and detachmentof the hook of the load-lifting device with a ring on the load at inaccessible, but visible to the slinger distance is solved by developing a hook with a pneumatic drive, the use of which allows to form the third level of equipment in the parking lot. This is achieved by providing rotation of the hook around the vertical axis by means of an electric motor and a reducer and the use of a pneumatic system that creates a reactive force in the desired direction and desired magnitude. With a hook weight of $120 \mathrm{~N}$, nozzle diameter of $0.01 \mathrm{~m}$, the specific pressure in the pneumatic system of the hook should be at least $0.027 \mathrm{MPa}$, and the use of the pneumatic system will allow to change the time damping free vibrations of the hook when the load is snagged, with inaccessible distance, reducing it from 10 min to zero.

The economic efficiency of the proposed three-level parking lot for agricultural machines will be ensured by the rational use of the volume of the room (hangar), as in the same area two to three times more machines will be stored, in the absence of machines for long-term storage hangar will be a warehouse for storage of agricultural products.

\section{References}

[1] Пат. 2396403 Российская Федерация, МПК С2, Е 04Н 6/14 (2006.01). Многоуровневый паркинг многоцелевого назначения и фасадная стена для его возведения / П. В. Плева (PatentNo 2396403 RussianFederation, C2, E 04H 6/14 (2006.01). Multi-level multi-purpose parking lot and facade wall for its construction). Applicant and the patent owner P. V. Pleva: заявитель и патентообладатель П. В. Плева. The No 2008131557/03 it is declared 30.07.2008. It is published 10.08.2010. Bulletin No. 22. (In Russian).

[2] Пат. 2551555 Российская Федерация, МПК С2, Е 04Н 6/18 (2006.01) Е 04Н 6/22 (2006.01). Паркинг / МайнерсРюдигер (Patent No 2551555 Russian Federation, C2, E 04H 6/18 (2006.01) E 04H 6/22 (2006.01). Parking area). Applicant and the patent owner Otto Wohr GmbH: заявительипатентообладательОТТО ВЁР ГМБХ.The No 2013110473/03 it is declared 28.07.2011. It is ОТТО ВеР ГМБХ published 20.09.2014. Bulletin No. 15. (InRussian).

[3] Пат. 2562994 Российская Федерация, МПК С1, Е 04Н 6/18 (2006.01). Горизонтальный автоматизированный паркинг / Н. В. Сенчишин, В. Н. Сенчишин. (PatentNo 2562994 RussianFederation, C1, E 04H 6/18 (2006.01). Horizontal automated parking). Applicant and the patent owner N. V. Senchishin: заявитель и патентообладательН. В. Сенчишин.The No 2014124014/03 it is declared 16.06.2014. It is published 10.09.2015. Bulletin № 25. (In Russian).

[4] M. Sai Vikram, N. Ayesha. Different types of parking spaces and multiple level car parking. International Journal of Research. In Advanced Engineering Technologies.Volume 6, Issue 2, 2017, pp. 339-346.

[5] Sonar R. Automatic underground car parking system. International Journal of Modern Trends in Engineering \& Research. 2017, No. 4, pp. 64-68. 
[6] Mahendran S., Sivasubramanian K., Pandiyan M.A. Design of multilevel car parking building. International Journal of Civil Engineering and Technology (IJCIET). Volume 9, Issue 11, 2018, pp. 1164-1169.

[7] Пат. 2652037 Российская Федерация, МПК С2, Е 04Н 6/18 (2006.01), Е 04Н 6/22 (2006.01). Паркинг для сельскохозяйственной техники / Н. Ф. Скурятин, А. В. Бондарев, Е. В. Соловьев и др. (Patent No 2652037 Russian Federation, C2, Е 04H 6/18 (2006.01), Е 04H 6/22 (2006.01). Parking for agricultural machinery). Applicant and the patent owner Belgorod State Agricultural University named after V. Gorin: заявитель и патентообладатель ФГБОУ ВО Белгородский ГАУ.The No 2017126414 it is declared 21.07.2017. It is published 24.04.2018. Bulletin No. 12. (In Russian).

[8] Пат. 2426683 Российская Федерация, МПК С1, В 66 С 1/34 (2006.01). Подъемный крюк / Пииспанен Ханну, ЛехтиненАри, Никкола Ярмо и др. (Patent No 2426683 Russian Federation, C1, B 66 C 1/34 (2006.01). Hoisting hook). Applicant and the patent owner BKOUNKREhJNS PLK: заявитель и патентообладатель КОУНКРЭЙНС ПЛК.The No 2010103016/11 it is declared 07.07.2008. It is published 20.08.2011. Bulletin No.23. (In Russian).

[9] Пат. 2238237 Российская Федерация, МПК С2, В 66 F 9/12 (2000.01). Подъемное устройство для перемещения стопки изделий, упаковки или груза / ПетерсЙоханнесАлойсиус Мари, СлагманФреркДирк, Ван ПинкстеренАдрианус. (Patent No 2238237 Russian Federation, C2, B 66 F 9/12 (2000.01). Lifting device for handling stacks of articles, packages or loads). Applicant and the patent owner FPS FOOD PROCESSING SYSTEMS B.V.: заявитель и патентообладатель ФПС ФУД ПРОСЕССИНГ СИСТЕМЗ Б.B.The No 2001130691/28 it is declared 14.04.2000. It is published 10.09.2003. Bulletin No. 25. (In Russian).

[10]Пат. 81179 Российская Федерация, МПК U1, В 66 С 23/00 (2006.01), В 66 С 23/62 (2006.01). Устройство для подъема и поворота груза / М. З. Левин, М. В. Уланов, А. Г. Давидчук и др. (Patent No 81179 Russian Federation, U1, B 66 C 23/00 (2006.01), B 66 C 23/62 (2006.01). Device for lifting and turning the load). Applicant and the patent owner CJSC Research and Production Center "Aquamarine": заявитель и патентообладатель ЗАО Научнопроизводственный центр”Аквамарин”. The No 2008134659/22 it is declared 25.08.2008. It is published 10.03.2009. Bulletin No. 7. (In Russian).

[11] Mechanics: Laboratory practicum on the course of physics: textbook / A. G. Zavodovsky, E. G. Nevzorova, N. I. Verlan et al. - Tyumen, 2006. 98 p. (In Russian).

[12] Trofimova T. I. Course of physics: a textbook for engineering students / T. I. Trofimova.Moscow: Academy, 2010. 558 p. (In Russian). 